\title{
Meltem
}

İzmir Akdeniz Akademisi Dergisi

No. 4, Kış 2018, 91-93, DOI 10.32325/iaad.2018.36

\section{Mültecilik, Kent Hakkı, İzmir}

\section{Mete Hüsünbeyi*}

Birleşmiş Milletler Mülteciler Yüksek Komiserliği'nin son Küresel Eğilimler raporuna göre 2017 sonu itibarılya her iki saniyede bir kişi, toplamda 68,5 milyon kişi yerinden edilmiş durumda. Bu insanların 25,4 milyonunu ülkelerindeki çatışmalar ve zulüm nedeniyle evlerini terk eden mülteciler oluşturmakta. Son 20 yılda mültecilerin yüzde 85'i gelişmekte olan ülkelerde bulunuyor.'

Türkiye geçmişte mülteciler için transit ülke konumdayken bugün aynı zamanda hedef ülke haline de gelmiştir. Göç İdaresi Genel Müdürlüğü’nün verilerine göre Türkiye'de 3,5 milyondan fazla kayıtlı Suriyeli bulunuyor; 300 bin civarında da Suriyeli olmayan mülteci yaşıyor. İzmir'de kayıtı Suriyeli mülteci sayısı 140 bin civarında.

\section{Mültecilik}

Mültecilik ve hakları 28 Temmuz 1951'de Cenevre'de imzalanmış Mültecilerin Hukuki Statüsüne Illişkin Sözleşme'de tanımlanmıştır. 1951 Sözleşmesi ve 1967 Protokolü’ne göre “mülteci” ırkı, dini, milliyeti, siyasi düşüncesi ve belirli bir gruba mensubiyetinden dolayı, zulüm görme tehdidinden ya da bu endişeden dolayı ülkesinden ayrılıp, başka ülkelere sığınma talebinde bulunan ve talebi kabul edilen kişidir. "Sı̆̆ınmacı", yukarıdaki gerekçelerden dolayı mültecilik başvurusunun sonucunu bekleyenler için kullanılmaktadır.

Türkiye'de mültecilik hakkı yalnız Avrupa Konseyi'ne üye ülkelerden gelenler için tanınmaktadır. 4 Nisan 2013'te kabul edilen Yabancılar ve Uluslararası Koruma Kanunu'nda (YUKK) "Avrupa ülkelerinde meydana gelen olaylar nedeniyle" ülkesinden ayrllanlara "mülteci" denilirken (Madde 61); "Avrupa ülkeleri dışında meydana gelen olaylar nedeniyle" ülkesinden ayrılanlar için "sığınmacı" karşılığı olarak "şartlı mülteci" ifadesi kullanılmaktadır (Madde 62). ${ }^{3}$

YUKK, Suriye dışından gelenler için düzenlenmişken, Suriye'den gelenler bu kanunun 91. maddesine dayanılarak 13 Ekim 2014'te çıkarılan Geçici Koruma Yönetmeliği'ne bağıdır. Diğer bir deyişle, Suriye dışından gelenler uluslararası koruma, Suriye'den gelenler geçici koruma kapsamındadır. Geçici koruma,

Ülkesinden ayrılmaya zorlanmış, ayrıldığı ülkeye geri dönemeyen, acil ve geçici koruma bulmak amacıyla kitlesel olarak veya bu kitlesel akım döneminde bireysel olarak sınırlarımıza gelen veya sınırlarımızı geçen uluslararası koruma talebi bireysel olarak değerlendirmeye alınamayan yabancılara sağlanan koruma

olarak tanımlanmıştır (Madde 3). ${ }^{4}$

Suriyeliler için birçok kavram ("geçici eğitim merkezi", "geçici barınma merkezi”, "geçici kimlik kartı" vb.) "geçici” olarak kullanılmaktadır. 2011'den beri Türkiye'de bulunan bu insanlar için geçicilik konumunun hâlâ sürmesi tartışmalı bir konudur. Ülkelerin yasalarının zulüm tehlikesi nedeniyle kendi ülkesinden ayrılanlara mülteci statüsü vermemesi, onların mülteci olmadıkları anlamına gelmez. Zira onları mülteci kılan, sığındıkları ülkelerin yasaları değil içinde bulundukları zorunlu koşullardır.

* Konak Kent Konseyi Mülteci Meclisi

1 Global Trends Forced Displacement in 2017 (Cenevre: UNHCR, 2018), 2, http://www.unhcr.org/5b27be547, erişim tarihi 13 Kasım 2018.

2 Mültecilerin Hukuki Statüsüne İlişkin Sözleşme,

http://www.goc.gov.tr/icerik6/multecilerin-hukuki-durumuna-iliskin-sozlesme_340_341_641_icerik, erişim tarihi 13 Kasım 2018.

3 Yabancılar ve Uluslararası Koruma Kanunu, http://www.goc.gov.tr/icerik6/yukk_327_328_329_icerik, erişim tarihi 13 Kasım 2018.

4 Geçici Koruma Yönetmeliği, http://www.goc.gov.tr/icerik6/gecici-koruma-yonetmeligi_333_336_1473_icerik, erişim tarihi 13 Kasım 2018. 


\section{Kent Hakkı}

"Hak, kısaca, kişilere hukuk düzenince tanınmış yetki olarak tanımlanabilir," diyor Rona Aybay ve ekliyor: "Tanınmış olan hakların eylemli olarak (fiilen) kullanılabilmesine olanak veren ve olabildiğince kusursuz işleyen bir toplum düzeninin de devletçe sağlanması gerekir." İnsan Hakları Evrensel Beyannamesi'ne göre herkesin "nerede olursa olsun hukuk kişiliğinin tanınması hakkı" vardır (Madde 6). Bu hüküm "insan hakları" kavramının coğrafi alanlardan, devlet sınırlarından bağımsız, "evrensel” niteliğini gösteren bir ilkedir. ${ }^{5}$ Beyannamenin 14 . maddesi de herkese zulüm karşısında başka ülkelerden mülteci olarak kabul talep etmek ve bu ülkelerce mülteci muamelesi görmek hakkını tanır.

Kent kuramcısı Henri Lefebvre, kent hakkı ile temel olarak bir kentte ikamet eden herkesin, ulus devlet düzeyinde vatandaş olsun ya da olmasın, o kent üzerinde hakkı olduğunun altını çizmiştir. Lefebvre'ye göre bu hak iki şekilde gündeme gelir: Söz konusu mekânı kullanma hakkı ve kent ile ilgili karar süreçlerinde söz sahibi olma hakkı. Bir diğer kent kuramcısı David Harvey mültecilerin kentin vazgeçilmez bir parçası olduğunu belirtmiştir. ${ }^{6}$

Bu yaklaşımlar uluslararası anlaşma, sözleşme ve beyannamelerde de karşılığını bulmuştur. Avrupa Kentte İnsan Haklarının Korunması Sözleşmesi, ilk maddesinde kenti “içinde yaşayanların tümüne ait kolektif bir mekân" olarak tanımlamaktadır.? 2005'te Porto Alegre'deki Dünya Sosyal Forumu'nda kabul edilen Dünya Kent Hakkı Şartı, kent sakinlerini "kalııı ya da geçici olarak kentte ikamet eden tüm insanlar" olarak tanımlar. Şart, kentte yaşayan hassas, kırılgan gruplara yönelik önlem alınmasını ve uygulanmasını öngörmektedir. Kent hakkı,

çocuklar, kadınlar, yaşıllar, yoksul ve düşük gelirliler, evsizler, engelliler, etnik azınlıklar, göçmen ve mülteciler, yerlerinden edilmişler gibi savunmasız grupları da ayrımcılık yapmadan kapsayacak şekilde tüm sakinlerin kentin olanaklarına eşit erişimi, yerel yönetime demokratik katılımlarının teşviki, temel hak ve özgürlüklerin yaygınlaştırılmaları ve güçlendirilmeleri

olarak tanımlanır. ${ }^{8}$

Kent hakkının kapsamının genişliği yasalarımızda da yer almaktadır. 3 Temmuz 2005 tarihli Belediye Kanunu’nun “Hemşehri hukuku” başlıklı 13. maddesine göre:

Herkes ikamet ettiği beldenin hemşehrisidir. Hemşehrilerin, belediye karar ve hizmetlerine katılma, belediye faaliyetleri hakkında bilgilenme ve belediye idaresinin yardımlarından yararlanma hakları vardır. [...] Belediye, hemşehriler arasında sosyal ve kültürel ilişkilerin geliştirilmesi ve kültürel değerlerin korunması konusunda gerekli çalışmaları yapar. ${ }^{9}$

Oysa 3 Nisan 1930 tarihli Belediye Kanunu'nun aynı maddesi şu tarifi yapmaktaydı: "Her Türk, nüfus kütüğüne yerli olarak yazıldığı beldenin hemşerisidir.” Görüldüğü gibi 1930'daki hemşeri tanımında "Türklük" ve "yerlilik" yer alırken 2005'te yenilenen halinde "herkes" ve "ikamet edilen yer" esas alınmıştır. Dolayısıyla hemşeri hukuku mültecileri de kapsamaktadır.

5 Rona Aybay, Insan Hakları Hukuku (İstanbul: İstanbul Bilgi Üniversitesi Yayınları, 2015), 3-4.

6 Bkz. Henri Lefebvre, Şehir Hakkı, çev. Işık Ergüden (İstanbul: Sel Yayıncılık, 2016); Kentsel Devrim, çev. Selim Sezer (İstanbul: Sel Yayıncılık 2013); Mekânın Üretimi, çev. Işık Ergüden (İstanbul: Sel Yayıncılık 2014); David Harvey, Asi Şehirler: Şehir Hakkından Kentsel Devrime Doğru, çev. Ayşe Deniz Temiz (İstanbul: Metis Yayınları, 2013).

7 Bkz. UCLG Committee on Social Inclusion, Participatory Democracy and Human Rights, European Charter for the Safeguarding of Human Rights in the City (Barcelona: United Cities and Local Governments, 2012), 10, https://www.uclg-cisdp.org/en/right-to-the-city/european-charter, erişim tarihi 13 Kasım 2018.

8 Cihan Uzunçarşılı Baysal, "Kent Hakkı”, Türkiye’de Hak Temelli Sivil Toplum Örgütleri: Sorunlar ve Çözüm Arayışları içinde, der. Özgür Gökmen (Ankara: STGM, 2011), 370.

9 Belediye Kanunu, http://www.mevzuat.gov.tr/MevzuatMetin/1.5.5393.pdf, erişim tarihi 13 Kasım 2018. 
